\title{
Acute promyelocytic leukemia: the study of $t(15 ; 17)$ translocation by fluorescent in situ hybridization, reverse transcriptase-polymerase chain reaction and cytogenetic techniques
}

M.L.L.F. Chauffaille, M.S. Figueiredo, R. Beltrani, S.V. Antunes, M. Yamamoto and J. Kerbauy
Disciplina de Hematologia e Hemoterapia, Escola Paulista de M edicina, Universidade Federal de São Paulo, São Paulo, SP, Brasil

\section{Correspondence}

M.L.L.F. Chauffaille

Disciplina de Hematologia e Hemoterapia, EPM , UNIFESP

Rua Botucatu, 740, 30 andar 04023-900 São Paulo, SP Brasil

Fax: +55-11-5571-8806

E-mail: chauffaill@ hemato.epm.br

Research supported by FAPESP (No. 97/05832-0)

Received April 3, 2000

Accepted M arch 2, 2001

\section{Abstract}

Acute promyelocytic leukemia (AML M3) is a well-defined subtype of leukemia with specific and peculiar characteristics. Immediate identification of $t(15 ; 17)$ or the PML/RARA gene rearrangement is fundamental for treatment. The objective of the present study was to compare fluorescent in situ hybridization (FISH), reverse transcriptasepolymerase chain reaction (RT-PCR) and karyotyping in 18 samples (12 at diagnosis and 6 after treatment) from 13 AML M3 patients. Bone marrow samples were submitted to karyotype G-banding, FISH and RT-PCR. At diagnosis, cytogenetics was successful in 10 of 12 samples, 8 with $\mathrm{t}(15 ; 17)$ and 2 without. FISH was positive in $11 / 12$ cases (one had no cells for analysis) and positivity varied from 25 to 93\% (mean: 56\%). RT-PCR was done in 6/12 cases and all were positive. Four of 8 patients with $\mathrm{t}(15 ; 17)$ presented positive RT-PCR as well as 2 without metaphases. The lack of RT-PCR results in the other samples was due to poor quality RNA. When the three tests were compared at diagnosis, karyotyping presented the translocation in $80 \%$ of the tested samples while FISH and RT-PCR showed the PML/ RARA rearrangement in $100 \%$ of them. Of 6 samples evaluated after treatment, 3 showed a normal karyotype, 1 persistence of an abnormal clone and 2 no metaphases. FISH was negative in 4 samples studied and 2 had no material for analysis. RT-PCR was positive in 4 (2 of which showed negative FISH, indicating residual disease) and negative in 2 . When the three tests were compared after treatment, they showed concordance in 2 of 6 samples or, when there were not enough cells for all tests, concordance between karyotype and RT-PCR in one. At remission, RT-PCR was the most sensitive test in detecting residual disease, as expected (positive in $4 / 6$ samples). An incidence of about $40 \%$ of 5 ' breaks and $60 \%$ of 3 ' breaks, i.e., bcr3 and bcr $1 /$ bcr 2 , respectively, was observed.
Key words

- Acute promyelocytic leukemia

- Karyotype

- FISH

- RT-PCR

- PM L/RARA gene rearrangement 


\section{Introduction}

Acute promyelocytic leukemia (AML M3) is characterized by the $t(15 ; 17)(q 22 ; q 11-$ 21) translocation described by Rowley et al. (1). This translocation reflects the molecular rearrangement of the PML gene, located at $15 \mathrm{q} 22$, with the RARA gene, located at $17 \mathrm{q} 21$ (2), and is considered to be critical for the pathogenesis of the disease since it blocks differentiation during the promyelocytic stage of myeloid maturation (3). PML has been shown to function as a tumor suppressor and RARA has differentiation-promoting and growth-suppressing activities, being essential for normal hematopoiesis. Furthermore, the expression of PML/RARA leads to disruption of PML nuclear body structures, resulting in dislocation of this growth-suppressor gene $(4,5)$ and its inhibition by the formation of heterodimers (6).

At first, anthracyclines and cytarabine were the treatment of choice for AML, but after the introduction of a vitamin A derivative, all-trans retinoic acid (ATRA), at the end of the 80's (7), a great improvement in remission rate has been observed. ATRA induces blasts and terminal promyelocyte differentiation followed by cell death (8). How ATRA overcomes the dominant negative effect of PML/RARA is not understood, but it seems that ATRA disrupts the interaction of the PML/RARA protein with the nuclear co-repressor/histone deacetylase complex that promotes transcriptional repression (6).

Treatment with ATRA alone may induce complete, though short-lived, remission in more than $80 \%$ of cases (9), but when combined with chemotherapy it leads to significant improvement in survival rate and lowers the incidence of relapse $(3,10)$.

Immediate identification of patients that would benefit from ATRA became of fundamental importance, since those that do not present the typical translocation will not go into remission. This identification is usually based on cytogenetics but $t(15 ; 17)$ is not detected in at least $10 \%$ of morphologic AML M3 due mainly to technical failure of cytogenetic analysis, to the presence of PML/ RARA fusion genes created by cryptic insertion events or to the analysis of cells not belonging to the neoplastic clone (erythroblasts) $(3,4)$. Thus, alternative methods such as fluorescent in situ hybridization (FISH) or reverse transcriptase-polymerase chain reaction (RT-PCR) for the detection of PML and RARA fusion genes or transcripts permit a faster identification (11).

When patients are in clinical or hematological remission, more sensitive methods should be used for the detection of residual disease. RT-PCR status after completion of therapy is of prognostic significance and emphasizes the importance of achievement of molecular remission as a prerequisite for long-term survival. RT-PCR allows identification of one abnormal cell out of $10^{4}-10^{6}$ $(12,13)$.

The objective of the present study was to evaluate and compare FISH, RT-PCR and karyotyping for the detection of residual AML M3 disease.

\section{Material and Methods}

Eighteen samples ( 12 obtained at diagnosis and 6 after treatment) from 13 patients with AML M3 were studied (Table 1) from March 1996 to May 1999. Diagnosis was made according to FAB criteria (14) after total blood counts, cytochemistry, immunophenotyping and cytogenetics. All patients presented typical AML M3 morphology.

A second evaluation for the detection of residual disease by cytogenetics, FISH and RT-PCR was done when remission was achieved.

Patients were treated with ATRA (45 mg $\mathrm{sqm}^{-1}$ day $^{-1}$ ) followed by daunorubicin (DNR; $40 \mathrm{mg} \mathrm{sqm}^{-1}$ day $^{-1 / 3}$ days) and cytarabine (araC; $200 \mathrm{mg} \mathrm{sqm}^{-1}$ day $^{-1} / 7$ days) as soon as white blood cell count exceeded $3,000 / \mathrm{mm}^{3}$, 
as suggested by Kanamaru et al. (8). After complete remission was obtained, three courses of consolidation chemotherapy were applied according to the following protocol: mitoxantrone (MIT; $7 \mathrm{mg} \mathrm{sqm}^{-1}$ day $^{-1 / 3}$ days) and $\operatorname{araC}\left(80 \mathrm{mg} \mathrm{sqm}^{-1}\right.$ day $^{-1} / 7$ days); DNR (50 mg sqm ${ }^{-1}$ day $^{-1} / 3$ days), araC (200 mg sqm $^{-1}$ day $^{-1} / 7$ days), etoposide (ETO; $100 \mathrm{mg}$ $\mathrm{sqm}^{-1}$ day $^{-1 / 5}$ days) and 6-mercaptopurine (6MP; $70 \mathrm{mg} \mathrm{sqm}^{-1}$ day $^{-1} / 5$ days); epirubicin (30 mg sqm ${ }^{-1}$ day $^{-1} /$ days 1 and 4) and araC (170 $\mathrm{mg} \mathrm{sqm}^{-1}$ day $^{-1 / 7}$ days). Maintenance consisted of six courses applied every 6 weeks of $\operatorname{araC}\left(170 \mathrm{mg} \mathrm{sqm}^{-1}\right.$ day $^{-1} / 5$ days), DNR (30 $\mathrm{mg} \mathrm{sqm}^{-1}$ day $^{-1} /$ days 1 and 4) and 6MP (70 mg sqm ${ }^{-1}$ day $^{-1} / 7$ days); araC (170 mg $\mathrm{sqm}^{-1}$ day $^{-1} / 5$ days) and MIT (5 mg sqm ${ }^{-1}$ day $^{-1 / 2}$ days); araC (170 mg sqm ${ }^{-1}$ day $^{-1 / 5}$ days), ETO (80 $\mathrm{mg} \mathrm{sqm}^{-1}$ day $^{-1} / 5$ days) and vinblastine (6 $\mathrm{mg} \mathrm{sqm}^{-1}$ day $^{-1}$ /days 1 and 8 ). Case 10 received only ATRA for induction but his consolidation and maintenance treatment was similar to that for the other patients.

Five bone marrow donor samples with normal karyotype (from normal persons, whose karyotypes were routinely studied before donation for transplant) served as the control group for FISH. The Ethics Committee of the institution approved the study and the samples were collected after obtaining informed consent from each patient.

\begin{tabular}{|c|c|c|c|c|c|c|c|}
\hline & Sample & Sex & Age & Date & Cytogenetics & FISH & Rearrangement \\
\hline \multirow[t]{3}{*}{1} & $A$ & M & 10 & $6 / 96$ & $46, X Y, t(15 ; 17)$ & $57 \%$ & w \\
\hline & $B$ & & & $6 / 97$ & W & $4 \%$ & Present ( $\left(3^{\prime}\right)$ \\
\hline & $\mathrm{C}$ & & & $4 / 99$ & $46, X Y$ & $3 \%$ & Negative \\
\hline 2 & A & M & 42 & $5 / 97$ & $46, X Y$ & $45 \%$ & W \\
\hline 3 & $A$ & M & 21 & $5 / 97$ & $46, X Y, t(15 ; 17)$ & $70 \%$ & Present (5') \\
\hline \multirow[t]{2}{*}{4} & A & M & 87 & $7 / 97$ & W & $48 \%$ & Present (5') \\
\hline & B & & & $8 / 97$ & w & W & Present (5') \\
\hline 5 & $A$ & $\mathrm{~F}$ & 30 & $7 / 97$ & W & $68 \%$ & Present (3') \\
\hline \multirow[t]{2}{*}{6} & $A$ & M & 38 & $10 / 97$ & $46, \mathrm{XY}, \mathrm{t}(15 ; 17)$ & $25 \%$ & Present (5') \\
\hline & B & & & $11 / 97$ & $46, X Y, t(15 ; 17)$ & w & Present (5') \\
\hline \multirow[t]{2}{*}{7} & $A$ & $\mathrm{~F}$ & 12 & $7 / 97$ & $46, X X, t(15 ; 17)$ & $57 \%$ & Present ( $\left.3^{\prime}\right)$ \\
\hline & B & & & $10 / 98$ & $46, X X$ & $7 \%$ & Present $\left(3^{\prime}\right)$ \\
\hline 8 & $A$ & $\mathrm{~F}$ & 33 & 9/98 & $46, X X, t(15 ; 17)$ & $75 \%$ & w \\
\hline 9 & $A$ & $\mathrm{~F}$ & 34 & 9/98 & $46, X X, t(15 ; 17)$ & w & w \\
\hline $10^{*}$ & $A$ & M & 32 & $10 / 98$ & $46, X Y$ & $4 \%$ & Negative \\
\hline 11 & $A$ & M & 26 & $10 / 98$ & $46, X Y$ & $55 \%$ & w \\
\hline 12 & $A$ & $\mathrm{~F}$ & 56 & $11 / 98$ & $46, X X, t(15 ; 17)$ & $79 \%$ & Present (3') \\
\hline 13 & $A$ & $\mathrm{~F}$ & 48 & $5 / 99$ & $46, X X, t(15 ; 17)$ & $93 \%$ & w \\
\hline
\end{tabular}

FISH data are reported as percentage of cells with rearrangement (normal $<10 \%$ ). *This sample was collected after therapy. $\mathrm{W}=$ without material (metaphase, cells or RNA); $\mathrm{M}=$ male; $\mathrm{F}=$ female. 


\section{Cytogenetics}

Bone marrow was submitted to two shortterm cultures with RPMI 1640 medium, 20\% fetal calf serum, L-glutamine (1\%) and antibiotics $(1 \%)$. Colcemid $(50 \mu \mathrm{l})$ was added for 30 min followed by $\mathrm{KCl}(75 \mathrm{mM})$, at room temperature, for $20 \mathrm{~min}$ and Carnoy's fixative for 4 times. Slides were prepared and submitted to G-banding (GTG) and 10 metaphases from each culture were analyzed with the aid of a computer karyotyping system (Applied Vision, Santa Clara, CA, USA). The karyotypes were printed with a laser printer (Lexmark) and the abnormalities described according to ISCN nomenclature (15) (Figure 1).

\section{Molecular cytogenetics (FISH)}

Part of the material fixed in Carnoy's was used to prepare slides for FISH, which was carried out according to the probe supplier's instructions (PML-RARA-Oncor, Gaithersburg, MD, USA). The slides were analyzed under a fluorescent microscope (Olympus BX60, Tokyo, Japan) with DAPI, rhodamine, FITC and triple bandpass filters. The best

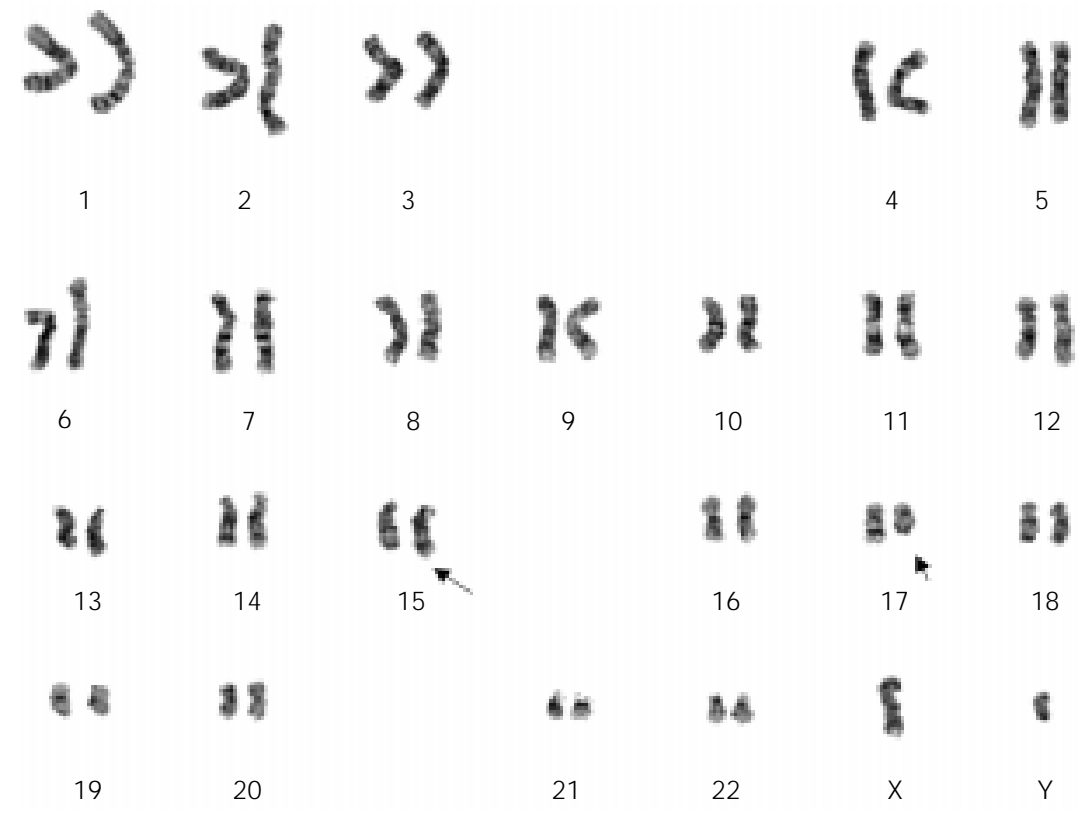

Figure 1. Karyotype showing t(15;17)(q22;q11). Arrows indicate t(15;17) translocation. images were captured through a CCD camera coupled to the microscope and connected to a computer equipped with karyotyping and FISH softwares (Applied Image). Slides showing more than $50 \%$ cells with fluorescent dots were selected for analysis. Two observers analyzed all slides. At least 200 isolated cells per slide were counted. A red dot (rhodamine) corresponded to the RARA (17q12) gene and a green dot (fluorescein) to PML (15q22). Thus, when one cell with two isolated red dots and two isolated green dots was seen, it was counted as normal, without rearrangement. When a cell with one isolated red dot, one isolated green dot and one fused green and red signal was seen it was considered to present rearrangement. Cases that presented more than $10 \%$ of cells with rearrangement were considered to be positive. As the differences between the two observers were less then $10 \%$, the results were summed and averaged.

\section{RNA extraction and RT-PCR}

Total cell RNA was extracted from leukocytes with guanidinium isothiocyanate and phenol-chloroform (16). cDNA was synthesized from $1 \mu \mathrm{g}$ of total cell RNA, using the Not I-d(T)18 primer (Pharmacia, Uppsala, Sweden) and M-MLV reverse transcriptase (Pharmacia), according to supplier's instructions and using supplier's buffers. First strand cDNA was amplified using $2.5 \mathrm{U}$ of Taq polymerase (Gibco-BRL, Gaithersburg, MD, USA), 30 pmol of each primer: M7 (sense) 5' ATGGCTTCGACGAGTTCAAG 3' and 06 (antisense) 5' GGCTTGTAGATGCGG GGTAG 3' (16), in a Progene thermocycler, under the following conditions: an initial cycle consisting of $3 \mathrm{~min}$ at $94^{\circ} \mathrm{C}, 90 \mathrm{~s}$ at $58^{\circ} \mathrm{C}$ and $2 \mathrm{~min}$ at $72^{\circ} \mathrm{C}$, followed by 35 cycles at $94^{\circ} \mathrm{C}$ for $1 \mathrm{~min}, 58^{\circ} \mathrm{C}$ for $1 \mathrm{~min}$ and $72^{\circ} \mathrm{C}$ for $1 \mathrm{~min}$, with a final extension step of $10 \mathrm{~min}$ at $72^{\circ} \mathrm{C}$. Amplified RT-PCR products were visualized on $2 \%$ agarose gel and photographed (Figure 2). 


\section{Results}

Eighteen samples from 13 patients were studied, 12 of them obtained at diagnosis and 6 after treatment. Seven of the 13 patients (53\%) were males and $6(46 \%)$ were females. All had typical clinical and laboratory aspects of AML M3 at diagnosis. Though case 10 had been diagnosed two years before and was in complete remission, he was included because he had gone into remission with ATRA. Four cases (1, 4, 6 and 7) were reevaluated a second or third time after treatment.

Table 1 shows the results of karyotyping, FISH and RT-PCR at diagnosis and after therapy.

Cytogenetics was successful at diagnosis in 10 of 12 samples $(83 \%): 8$ of them presented $\mathrm{t}(15 ; 17)(\mathrm{q} 22 ; \mathrm{q} 12)$ and 2 had a normal karyotype. The lack of karyotyping results in 2 samples (cases 4 and 5) was due to the absence of metaphases or insufficient material.

Among 6 samples evaluated a second time after treatment, two (samples B from cases 1 and 4) did not present enough material for cytogenetics, three (C from case 1, B from case 7 and $A$ from 10) presented a normal karyotype and one (sample B from case 6) showed persistence of the abnormal clone.

The results of FISH are reported as percentage and the 12 cases studied at diagnosis were positive except for case 9 that did not have sufficient material for analysis. Positivity ranged from 25 to $93 \%$ (mean, $56 \%$ ).

There was a decrease in the percentage of cells with rearrangement (or, in other words, cells that became negative, $<10 \%$ ) in the samples from patients evaluated after therapy (1, 6, 7 and 10), except for cases 4 and 6 for whom there was no material for FISH.

The control group for FISH presented a mean of $5.8 \%$ cells with rearrangement with a standard deviation of 3.3466 , so the limit for the normal value was set at $9.14 \%$, simi- lar to the $<10 \%$ value indicated by the probe supplier.

In the molecular study, RNA samples that presented $18 \mathrm{~S}$ and $28 \mathrm{~S}$ bands after electrophoresis were considered satisfactory. Cases in which RT-PCR amplification was not possible and whose RNA electrophoresis showed degraded material were considered to have technical problems and to be without RNA (Table 1).

All procedures were carried out with a negative control for amplification (without cDNA), a positive control for amplification (B-actin), negative control for rearrangement (normal person sample) and a positive control for rearrangement (NB4 cell lineage).

At first we tried amplification with the same primers as Castaigne et al. (17) without success. Then, some changes were introduced and checked with the NB4 cell lineage.

Using the M7-01 (M7: 5' ATg gCT TCg ACg AgT TCA Ag 3' and 01: 5' CCA AgC TTC TTg CAg CCC TCA CgA 3') primers and having NB4 as template it was possible to amplify a fragment with less than $250 \mathrm{bp}$, which corresponded to the 230-bp fragment found by Castaigne et al. (17). Then, by semi-nested RT-PCR using as template the product of the former RT-PCR and as primers the M7-06 combination (M7: 5' ATg



Figure 2. Agarose $2 \%$ gel electrophoresis of RT-PCR products. Lane 1, 250-bp amplification fragment using primers M7-01; lane 2, 50-bp marker; lanes 3 and 4, amplification fragments using M7-06 primers being in lane 3, 350-bp fragment and in lane 4, the 150 bp corresponding to $\mathrm{PML}$ gene breakpoints bcr $1 /$ bcr3 and bcr1/bcr2, respectively. 
gCT TCg ACg AgT TCA Ag 3' and 06: 5' ggC TTg TAg ATg Cgg ggT Ag 3'), a product of approximately $150 \mathrm{bp}$ was obtained. Using the M7-06 pair of primers we amplified fragments of $150 \mathrm{bp}$ in some of our samples and of $350 \mathrm{bp}$ in others, depending on the breakpoint of the PML gene, i.e., bcr $1 /$ bcr 2 or bcr 3 , respectively (Figure 3 , Table 1).

Four of 8 patients with $t(15 ; 17)$ in the karyotype also presented the molecular rearrangement by RT-PCR. But the lack of results in 6 other samples was due to poor quality RNA. Two patients with a normal karyotype also presented poor quality RNA and two cases that did not show karyotyping results (cases 4 and 5) presented positive RT-PCR.

Among the cases reevaluated after therapy, in the second analysis (1 year after diagnosis) case 1 presented the molecular rearrangement by RT-PCR, though karyotype and FISH were negative and RNA was of poor quality at diagnosis. At the third evaluation (3 years after diagnosis) RT-PCR was negative. Case 4, who had gone into early remission, presented persistence of positive RT-PCR one month after diagnosis. Case 6 was not considered to be in remission after one month of treatment (bone marrow with $3.4 \%$ of blasts and $16 \%$ of promyelocytes). His karyotype showed the presence of translocation as well as positive RT-PCR. Case 7, at the second evaluation was in maintenance chemotherapy, had normal karyotype and FISH but positive RT-PCR. Case 10 was included because he was an AML M3 patient who went into remission with ATRA,

Figure 3. Schematic diagram of the localization of the primers in the PML/RARA CDNA fusion (10).

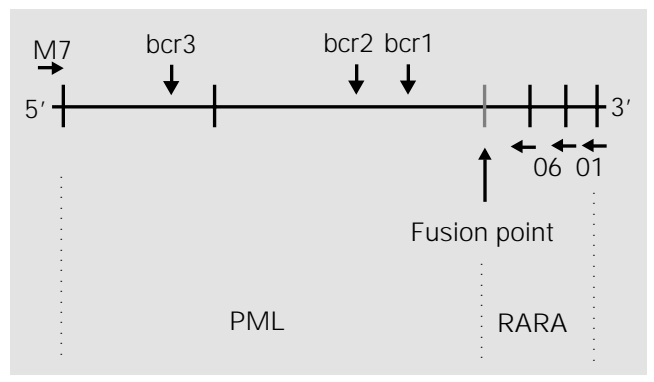

received the same protocol for consolidation and maintenance and showed negative RTPCR as well as FISH and karyotype after therapy.

In 6 of 18 samples it was not possible to repeat the RT-PCR due to insufficient material.

\section{Discussion}

AML M3 is characterized by bleeding and used to be considered a poor prognosis leukemia, since most patients died due to disseminated intravascular coagulation and fibrinolysis. However, patients who overcame these initial problems and achieved remission with anthracyclines and cytarabine had a better survival. A drastic change in therapy occurred with the introduction of ATRA in $1986(7,18)$.

Identification of $\mathrm{t}(15 ; 17)$ or its molecular equivalent, the rearrangement of genes PML/ RARA, continues to be the reason for cytogenetic, FISH and RT-PCR studies in AML M3. Patients carrying this abnormality have a good response to ATRA therapy, the associated coagulopathy resolves promptly, usually within the first $48 \mathrm{~h}$ and remission can be achieved in a high proportion of patients with an increased survival rate when associated with conventional chemotherapy (19). As expected, we observed the translocation in $80 \%$ of the patients at diagnosis by karyotyping (between 70 and 95\%) (19-21), but in $100 \%$ of them when the results of the three methods were summed. Although RT-PCR is considered to be the most valuable, it is helpful to use FISH and karyotyping for diagnosis, as demonstrated in the present study and by others (or even different methods like PML immunofluorescence with specific antibodies) $(4,5,21)$.

In the absence of the usual cytogenetic translocation, though with typical morphology, two events may occur: normal karyotype or other abnormalities, named variants, such as $\mathrm{t}(5 ; 17)(\mathrm{q} 32 ; \mathrm{q} 11), \mathrm{t}(11 ; 17)(\mathrm{q} 23 ; \mathrm{q} 11)$ 
or $\mathrm{t}(11 ; 17)(\mathrm{q} 13 ; \mathrm{q} 11)$, involving genes NPM/ RARA, PLZF/RARA or NuMA/RARA, respectively. We did not observe variant translocations $(22,23)$ in the present study.

Some investigators considered that there was geographical variability, with some areas presenting a higher incidence of translocations than others, but this difference was considered to be due to technical problems since the percentage of positive cells detected by the direct method is lower than that detected in 24-48-h cultures (24). We found two cases with normal karyotypes (2 and 11) by performing $24-\mathrm{h}$ cultures. This proves that cytogenetics alone is no longer considered the optimal method. Despite these limitations, conventional cytogenetics should continue to be used since complex translocations involving more than two chromosomes or other abnormalities in addition to the $(15 ; 17)$ translocation are detected only by this method.

When there is no abnormality in the karyotype the molecular rearrangement may be detected by FISH or RT-PCR and the clinical course will be equal to that of patients with the classical translocation. Two cases with normal karyotypes presented positive FISH in the present series.

The standardization of the PML/RARA rearrangement by FISH and RT-PCR was required for fast identification at diagnosis as well as a better evaluation of minimal residual disease or even its quantification by FISH.

Despite the main concern about obtaining enough material for all the tests we intended to perform (morphology, cytochemistry, immunophenotyping, cytogenetics, FISH and RT-PCR), in some cases there was insufficient material, so that not all tests could be performed. Whenever possible collection was repeated but even then sometimes the procedure was not successful due to technical problems or early coagulation, which is not rare in AML M3. We had some difficulties in obtaining material from some patients in remission or others still receiving chemotherapy due to marrow hypoplasia secondary to drugs (cases 1, 4 and 6 at the time of collection of the second sample).

At diagnosis, FISH was more sensitive than cytogenetics in detecting rearrangements, and besides confirming the abnormality in 7 cases with the translocation (cases $1,3,6,7,8,12$ and 13), it was positive in the cases with normal karyotypes (cases 2 and 11) and in those that did not show metaphases (4 and 5). Furthermore, FISH is a fast method providing results usually within 2 days after collection.

Comparing cytogenetics to RT-PCR at diagnosis and when we had satisfactory RNA, there was a good correlation between the two methods (cases 3, 6, 7 and 12). In two cases that did not have mitoses (cases 4 and 5) RT-PCR as well as FISH were positive.

At remission, comparison of the three methods showed that RT-PCR, as expected, was the most sensitive in detecting residual disease. An interesting observation was the presence of persistent positive RT-PCR one year after diagnosis in two cases (cases 1 and 7) but case 1 suffered some delays in the chemotherapy schedule due to retarded marrow recovering and in fact, was post-consolidation at the time of the second evaluation.

Later, 2 or 3 years after diagnosis (cases 10 and 1, respectively), RT-PCR was negative. It seems that the time for RT-PCR to convert to negativity is variable, with positivity continuing until about 3 months after consolidation. It is the persistence of positivity or positivity subsequent to negativity that represents a threat of relapse. This is why the molecular monitoring strategies in which only RT-PCR is determined post-consolidation fail to predict relapse in the majority of patients who suffer it (21).

Case 4 did not present material for karyotyping or FISH, but had positive RT-PCR one month after therapy, already in complete clinical and hematological remission, indi- 
cating the persistence of residual disease, as expected within such a short period after treatment.

Case 6 did not show hematological remission at reevaluation after treatment and presented persistence of an abnormal karyotype and positive RT-PCR, while FISH analysis was not possible, preventing the quantification of residual cells.

Case 7 was similar to case 1, presenting positive RT-PCR at first reevaluation, indicating the presence of residual disease. In the near future, sequential RT-PCR will show her evolution since the patient continues to be under treatment.

Case 10 did not have karyotyping, FISH or RT-PCR at diagnosis and was treated for induction with ATRA (45 mg sqm ${ }^{-1}$ day $^{-1}$ ) alone and then received consolidation and maintenance treatment as the protocol proposed. At the time of collection he was 6 months out of therapy ( 2 years after diagnosis) and the three tests were negative, indicating undetectable residual disease.

RT-PCR positivity after treatment may mean amplification of one abnormal cell. FISH may show the percentage of a greater quantity of abnormal cells, above $10 \%$, which is the upper normal limit. This number does not mean that normal subjects have rearrangement, but represents the cells that eventually have two chromosomes close to each other, mimicking juxtaposition. Our interpretation is that when the interphases were properly swollen there was a lower number of cells with rearrangement since the chro- mosomes were more distant inside the nucleus. This is why the quantification is valid only above $10 \%$.

Three different genomic breakpoints may occur in the PML gene on chromosome 15q: PML intron 3 to RARA intron 2 yielding a PML exon 3-RARA exon 3 fusion transcript (bcr3 or short form); PML intron 6 to RARA intron 2 yielding a PML exon 6-RARA exon 3 fusion (bcr1 or long), and PML exon 6 to RARA intron 2 yielding a PML partial exon 6-RARA exon 3 fusion transcript (bcr2 or variable form) (6). We observed an incidence of about $40 \%$ of 5 ' breaks and $60 \%$ of 3' breaks, i.e., bcr3 and bcr1/bcr2, respectively, similar to other published series (21, 25). Some authors have suggested that the presence of the 5' (bcr3) PML breakpoint is associated with an increased risk of relapse $(12,25)$, while others have denied this hypothesis, arguing that there are insufficient data to justify the use of the PML breakpoint to guide the treatment approach $(21,26,27)$.

It was possible to standardize the two molecular methods, FISH and RT-PCR, and compare them. FISH was technically more useful at diagnosis due to its rapid execution, sensitivity and accuracy. After treatment, RT-PCR is the method of choice.

Studies with newer technologies such as real time PCR, which permits the quantification of disease-related transcripts relative to an internal control and may indicate patients at particular risk of relapse during therapy, are needed.

\section{References}

1. Rowley J D, Golomb HM \& Dougherty C (1977). 15/17 translocation, a consistent chromosomal change in acute promyelocytic leukaemia. Lancet, 1: 549-550.

2. Biondi A, Rambaldi A, Alcalay M, Pandolfi PP, LoCoco F, Diverio D, Rossi V, Mercarelli A, Longo $L \&$ Zanguilli $D$ (1991). RARA gene rearrangement as a genetic marker for diagnosis and monitoring in APL. Blood, 77: 1418-1422.

3. Allford $S$, Grimwade D, Langarbeer $S$, Duprez E, Saurin A, Chatters S, Walker H, Roberts P, Rogers J , Bain B, Patterson K, McKeman A, Freemont $P$, Solomon $E$, Burnett A, Goldstone A \& Linch D (1999). Identification of the $t(15 ; 17)$ in $A M L F A B$ types other than M3: evaluation of the role of molecular screening for the PML/ RARA rearrangement in newly diagnosed AML. British J ournal of Haematology, 105: 198-207.

4. LoCoco F, Diverio D, Falini B, Biondi A, Nenvi C \& Policci PG (1999). Genetic diagnosis and molecular monitoring in the 
management of acute promyelocytic leukemia. Blood, 94: 12-22.

5. Diverio D, Rossi V, Avvisati G, de Santis S, Pistilli A, Pane F, Saglio G, Martinelli G, Petti MC, Santoro A, Pelicci PG, Mandelli F, Biondi A \& LoCoco FL (1998). Early detection of relapse by prospective RTPCR analysis of the PM L/RARalpha fusion gene in patients with APL enrolled in the GIMEMA AIEOP multicenter AIDA trial. Blood, 92: 784-789.

6. Willman CL (1999). Molecular evaluation of acute myeloid leukemia. Seminars in Hematology, 36: 390-400.

7. Huang ME, Ye YC, Chen SR, Chai J R, Lu J X, Zhoa L, Gu LJ \& Wang ZY (1988). Use of all-trans retinoic acid in the treatment of acute promyelocytic leukemia. Blood, 72: 567-572.

8. Kanamaru A, Takemoto $\mathrm{Y}$, Tanimoto M, Murakami H, Asou N, Kobayashi T, Kuriyama $K$, Ohmoto $E$, Sakamaki $H$, Tsubari K, Hiraoka A, Yamada O, Oh H, Saito K, Matsuda S, Minato K, Ueda T \& Ohno O (1995). All trans retinoic acid for the treatment of newly diagnosed acute promyelocytic leukemia. J apan Adult Study Group. Blood, 85: 1202-1206.

9. J ansen J H, Ridder MC, Geertsma WMC, Erpelinck CAJ, van Lom K, Smit EME, Slater R, Reijden BA, Greef GE, Sonneveld P \& Lowenberg B (1999). Complete remission of $t(11 ; 17)$ positive acute promyelocytic leukemia induced by all trans retinoic acid and granulocyte colony stimulating factor. Blood, 94: 39-45.

10. Fenaux $P$, Chastang $C$, Chevret $S$, Sanz $M$, Dombret $H$, Archimbaud $E$, Fey $M$, Rayon C, Huguet F, Sotto JJ , Gardin C, Makhoul PC, Travade P, Solary E, Fegueux $N$, Bordessoule D, Miguel J S, Link $H$, Desablens B, Stamatoullas A, Deconick E, Maloisel F, Castaigne S, Preudhomme $C \&$ Degos L (1999). A randomized comparison of all trans retinoic acid (ATRA) followed by chemotherapy and ATRA plus chemotherapy and the role of maintenance therapy in newly diagnosed APL. Blood, 94: 1192-1200.

11. Schad CR, Hanson CA, Paietta E, Caasper J , J alal SM \& Dewald GW (1994). Efficacy of fluorescent in situ hybridization for de- tecting PML/RARA gene fusion in treated and untreated acute promyelocytic leukemia. Mayo Clinic Proceedings, 69: 10471053.

12. Fukutani $H$, Naoe $T$, Ohno $R$, Yoshida $H$, Kiyoi H, Miyawaki S, Morishita H, Sano F, Kamibayashi H \& Matsue K (1995). Prognostic significance of the RT-PCR assay of PML-RARA transcripts in acute promyelocytic leukemia. Leukemia, 9: 588-593.

13. Warrell RP, Barret AJ, Pandolfi PP \& Willman CL (1997). Acute myelocytic leukemia. 1999 Education Program, American Society of Hematology, 120-137.

14. Bennett J M, Catovsky D, Daniel MT, Flandrin G, Galton DAG, Gralnick HR \& Sultan C (1976). Proposals for the classification of the acute leukemias. FrenchAmerican-British (FAB) co-operative group. British J ournal of Haematology, 33: 451-458.

15. Mittelman F (1995). International System for Human Cytogenetics Nomenclature (ISCN-An). S. Karger, Basel.

16. Chomczynski $P \&$ Sacchi N (1987). Single step method of RNA isolation by acid guanidinium thiocyanate-phenol chloroform extraction. Annals of Biochemistry, 162: 156-159.

17. Castaigne $S$, Balitrand $N$, de The $H$, Dejean A, Degos L \& Chomienne C (1992). A PML/retinoic acid receptor alpha fusion transcript is constantly detected by RNA-based polymerase chain reaction in acute promyelocytic leukemia. Blood, 79: 3110-3115.

18. Warrell RP, de The $H$, Wang $Z Y \&$ Degos L (1993). Acute promyelocytic leukemia. New England J ournal of Medicine, 329: 177-189.

19. Fenaux $\mathrm{P}$, Castaigne $\mathrm{S}$, Dombret $\mathrm{H}, \mathrm{Ar}-$ chimbaud E, Duarte $M$, Morel P, Lamy T, Tilly H, Guerci A \& Maloisel F (1992). Alltransretinoic acid followed by intensive chemotherapy gives a high complete remission rate and may prolong remissions in newly diagnosed acute promyelocytic leukemia. A pilot study on 26 cases. Blood, 80: 2176-2181.

20. Mancini M, Nanni M, Cedrone M, Diverio D, Awisati G, Riccioni R, DeCuia MR, Fenu S \& Alimena G (1995). Combined cytoge- netic, FISH and molecular analysis in acute promyelocytic leukemia at diagnosis and in complete remission. British J ournal of Haematology, 91: 878-884.

21. Burnett AK, Grimwade D, Solomon E, Wheatley K \& Goldstone AH (1999). Presenting white blood cell count and kinetics of molecular remission predict prognosis in APL treated with all-trans retinoic acid: result of the randomized MRC trial. Blood, 93: 4131-4143.

22. Zelent $A$ (1998). PCR cloning of $N$ terminal RAR isoforms and APL associated PLZF-RAR alpha fusion proteins. Methods in Molecular Biology, 89: 307-332.

23. Wells RA, Hummel J L, De Koven A, Zipursky A, Kirby M, Dube I \& Kamel-Reid $S$ (1996). A new variant translocation in acute promyelocytic leukemia: molecular characterization and clinical correlation. Leukemia, 10: 735-740.

24. Berger R, Bernheim A, Daniel MT, Valensi F \& Flandrin G (1983). Cytological types of mitosis and chromosome abnormalities in acute leukemia. Leukemia Research, 7: 221-236.

25. Tashiro S, Tanaka K, Asou H, Kyo T, Dohy H, Sukuri K \& Kamada N (1993). Detection of PML/RARA rearrangements by PCR using genomic DNA in patients with APL. J apanese J ournal of Cancer Research, 84: 110-113.

26. Vahdat L, Maslak P, Miller WH, Eardley A, Heller G, Scheinberg DA \& Warrell RP (1994). Early mortality and the retinoic acid syndrome in acute promyelocytic leukemia: impact of leukocytosis, low-dose chemotherapy, PML/RAR-alpha isoform and $C D 13$ expression in patients treated with ATRA. Blood, 84: 3843-3849.

27. Fukutami $H$, Naoe $T$, Ohno $R$, Yoshida $H$, Miyawaki S, Shimazaki C, Miyake T, Nakayama Y, Kobayashi H \& Goto S (1995). Isoforms of PML-retinoic acid receptor alpha fused transcripts affect neither clinical features of acute promyelocytic leukemia nor prognosis after treatment with all-trans retinoic acid. The Leukemia Study Group of the Ministry of Health and Welfare (Kosheisho) (1995). Leukemia, 9: 1478-1482. 